\title{
Plasmid-encoded genes specifying aniline oxidation from Acinetobacter sp. strain YAA
}

\author{
Toshiki Fujii, Masahiro Takeo and Yoshimichi Maeda
}

Himeji Institute of Technology, Department of Applied Chemistry, 2167 Shosha, Himeji, Hyogo, 671-22 Japan
Author for correspondence: Yoshimichi Maeda. Tel/Fax: +81792674891. e-mail: takeo@chem.eng.himeji-tech.ac.jp

Keywords: Acinetobacter, aniline oxidation, biodegradation

\section{INTRODUCTION}

Aniline and its derivatives have been widely used as materials for the synthesis of chemical products such as herbicides and dyes, and released into the environment during their use. Since they are known to be toxic and carcinogenic to living organisms (Lyons et al., 1985), many researchers have paid attention to their fate in the environment (Lyons et al., 1984; Amador \& Alexander, 1991). The major route for the breakdown of anilines has been found to be by biodegradation (Lyons et al., 1984).

Several authors have studied bacteria that are able to degrade aniline, toluidines and chloroanilines, and some catabolic pathways for the degradation of anilines by bacteria have been elucidated. Firstly, anilines are converted to the corresponding catechols via one or more oxidative steps including deamination. The resultant catechols are degraded through either the ortho(Aoki et al., 1983; Zeyer et al., 1985; Loidl et al., 1990) or the meta-cleavage pathway (McClure \& Venables, 1986; Konopka et al., 1989; Fuchs et al., 1991). Like other aromatic compound degradative plasmids, TOL, $\mathrm{NAH}, \mathrm{SAL}$ and so on, plasmids encoding the ability to

Abbreviation: C230, catechol 2,3-dioxygenase.

The GenBank/EMBUDDBJ accession number for the partial $7.4 \mathrm{~kb}$ sequence reported in this paper is D86080. utilize aniline have been recognized. Plasmid pCIT1 carried in Pseudomonas sp. strain CIT1 is about $100 \mathrm{~kb}$ in size and contains the aniline oxidase and catechol 2,3dioxygenase (C23O) genes on a $42 \mathrm{~kb}$ Sau3A fragment (Anson \& Mackinnon, 1984; Meyers, 1992). Pseudomonas putida UCC 2 bears PTDN1 which contains the catabolic genes for aniline, toluidines and $m$-toluate within a $26 \mathrm{~kb}$ region bounded by direct-repeat sequences (Saint et al., 1990). Recently, a $9.3 \mathrm{~kb}$ fragment of pTDN1 has been sequenced and found to encode several ORFs (Fukumori \& Saint, 1995). These ORFs were predicted to encode large and small subunits of terminal dioxygenase, an electron-transfer protein, a LysR-type regulatory protein and a glutamine synthetase-like protein. However, the detail is still unclear, because the sequence data have not been published.

In this paper, we report the cloning of the genes that convert aniline and o-toluidine to the corresponding catechols from plasmid DNA of Acinetobacter sp. strain YAA. The expression of these genes in Escherichia coli was confirmed by identification of the metabolites from aniline or $o$-toluidine by GC-MS.

\section{METHODS}

Media and culture conditions. A mineral salts medium (MSA) consisting of $1.73 \mathrm{~g} \mathrm{~K}_{2} \mathrm{HPO}_{4}, 0.68 \mathrm{~g} \mathrm{KH}_{2} \mathrm{PO}_{4}, 1.0 \mathrm{~g} \mathrm{NH}_{4} \mathrm{NO}_{3}$, $0.1 \mathrm{~g} \mathrm{MgSO}_{4} .7 \mathrm{H}_{2} \mathrm{O}, 0.03 \mathrm{~g} \mathrm{FeSO}_{4} .7 \mathrm{H}_{2} \mathrm{O}, 0.03 \mathrm{~g} \mathrm{FeCl}_{3}$, 
Table 1. Bacterial strains and plasmids

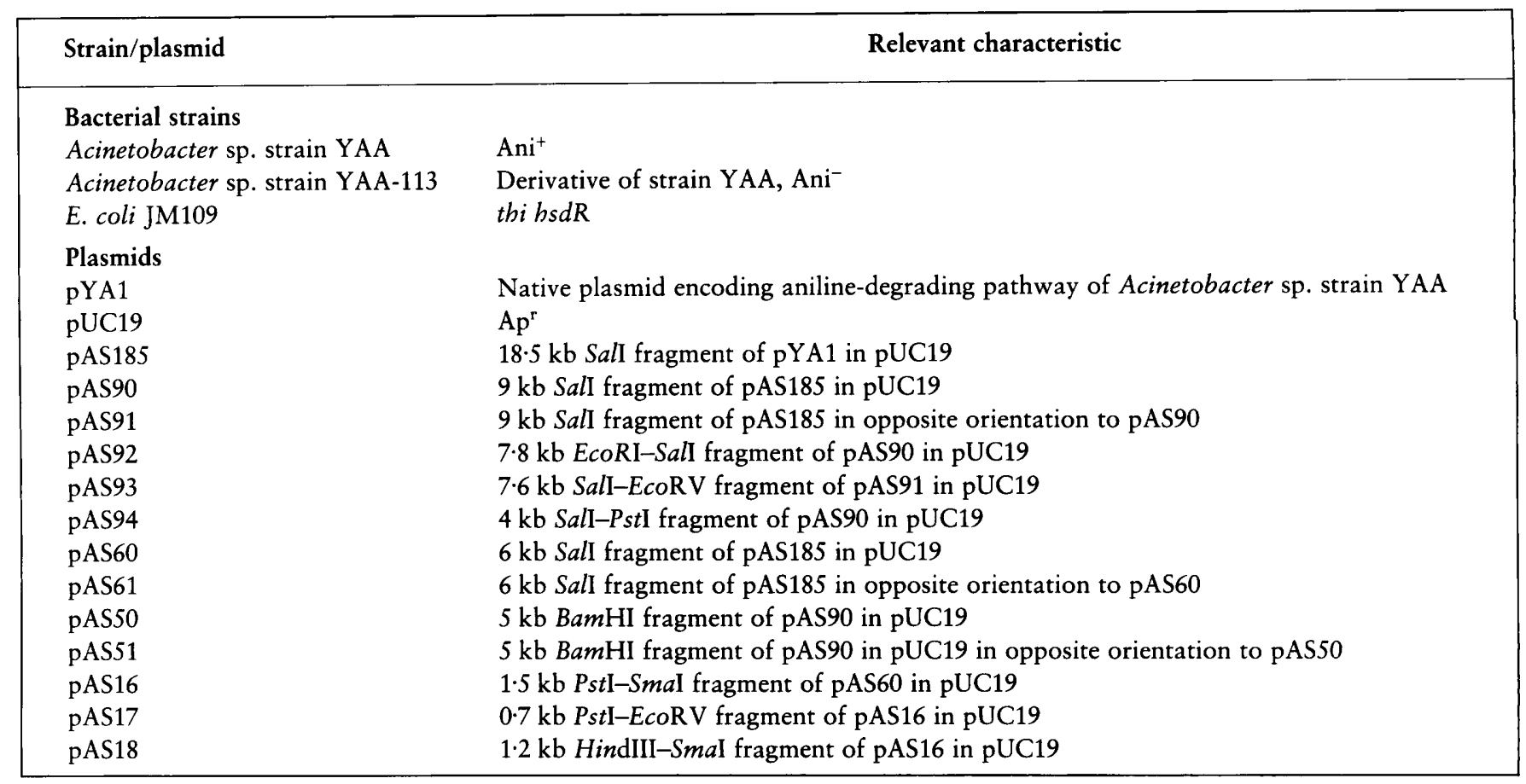

$0.02 \mathrm{~g} \mathrm{CaCl}_{2} .2 \mathrm{H}_{2} \mathrm{O}, 0.03 \mathrm{~g} \mathrm{MnSO}_{4} . \mathrm{H}_{2} \mathrm{O}$ and $0.3 \mathrm{~g}$ aniline as the sole source of carbon in 11 distilled water, $\mathrm{pH} 7 \cdot 0$, was used for screening and cultivation of aniline-assimilating bacteria. MSS medium supplemented with $1.0 \mathrm{~g}$ disodium succinate $\mathrm{l}^{-1}$, instead of aniline, was also used as a mineral salts medium. LB medium containing $10 \mathrm{~g}$ Bacto-peptone (Difco), $5 \mathrm{~g}$ Bacto-yeast extract (Difco), $10 \mathrm{~g} \mathrm{NaCl}$ in 11 distilled water, $\mathrm{pH} 7 \cdot 0$, was used as a rich medium. These media were solidified with $1.5 \%$ agar for plate growth. For propagation and maintenance of vector-based plasmids in the host, ampicillin was added at $50 \mu \mathrm{g} \mathrm{ml}^{-1}$ to the media described above.

Isolation and identification of aniline-assimilating bacteria. Aniline-assimilating bacteria were isolated from the activated sludge of Wakagawa final waste-water treatment facility (Wakayama, Japan), which treats waste-waters from chemical plants and textile-dyeing factories. A $300 \mathrm{ml}$ Erlenmeyer flask containing $100 \mathrm{ml} \mathrm{MSA} \mathrm{medium} \mathrm{and} \mathrm{the} \mathrm{activated} \mathrm{sludge}$ $(0.5 \%, \mathrm{w} / \mathrm{v})$ was shaken at 120 r.p.m. and $30^{\circ} \mathrm{C}$ on a rotary shaker for 1 week. The culture was spread onto MSA agar plates and incubated at $30^{\circ} \mathrm{C}$. The bacteria able to form a colony on the plates were regarded as aniline-assimilating bacteria. The isolate was characterized by taxonomic studies based on Hasegawa (1985), and identified according to the criteria of Bergey's Manual of Systematic Bacteriology (Juni, 1984). The partial sequences of $16 \mathrm{~S}$ ribosomal RNA were used for the identification as described by Rochelle et al. (1995). For preliminary identification at species level, the multiple-test system API $20 \mathrm{NE}$ (bioMérieux-Vitek) was also employed.

Bacterial strains and plasmids. The bacterial strains and plasmids used and constructed in this study are listed in Table 1.

Curing experiment. Acridine orange was added at a final concentration of $300 \mu \mathrm{g} \mathrm{ml}^{-1}$ to $\mathrm{LB}$ medium inoculated with about $10^{6}$ exponential-phase cells per $\mathrm{ml}$. After $24 \mathrm{~h}$ incubation at $30^{\circ} \mathrm{C}$, the culture was diluted with saline and plated out onto LB agar plates. The colonies appearing on the plates were replicated onto MSA plates to examine aniline-assimilation ability.

Methods for DNA extraction, analysis and cloning. Plasmid DNA was isolated by the alkaline extraction procedure (Birnboim \& Doly, 1979), followed by $\mathrm{CsCl} /$ ethidium bromide equilibrium ultracentrifugation $\left(100000 \mathrm{~g}, 20^{\circ} \mathrm{C}, 16 \mathrm{~h}\right)$ for purification. Restriction endonuclease digestion and DNA ligation were done according to the instructions of the enzyme suppliers (Takara Shuzo and TOYOBO). Transformation was carried out according to the methods of Sambrook et al. (1989).

Southern hybridization was performed according to established procedures (Southern, 1975). EcoRI-digested plasmid DNAs were separated by electrophoresis through $0.7 \%$ agarose gel and Southern-blotted onto Hybond $\mathrm{N}+$ nylon membranes (Amersham). DNA fragments were fluoresceinlabelled by using a Fluorescein Gene Images random prime module (Amersham) to prepare probes. Hybridization, stringency washes and signal detection were conducted with a Fluorescein Gene Images dioxetane detection module (Amersham) according to the manufacturer's instructions.

Oxygen uptake. Fresh cells, pre-grown in $40 \mathrm{ml} \mathrm{LB}$ medium, were harvested by centrifugation at $8000 \mathrm{~g}$ and $4{ }^{\circ} \mathrm{C}$ for $10 \mathrm{~min}$ and washed with $10 \mathrm{mM}$ potassium phosphate buffer $(\mathrm{pH} \mathrm{7 \cdot 0)}$. Cells were suspended in $100 \mathrm{ml}$ MSA medium to obtain aniline-induced cells or MSS medium to obtain aniline-noninduced (succinate-grown) cells, and incubated at $30^{\circ} \mathrm{C}$ with rotary shaking for $24 \mathrm{~h}$. The cells were harvested, washed twice with phosphate buffer and oxygen uptake was measured polarographically at $30^{\circ} \mathrm{C}$ using a Clark-type oxygen electrode (YSI 5750, Yellow Springs Instruments). Reaction mixtures contained $100 \mathrm{mg}$ aniline $\mathrm{l}^{-1}$ and washed cells $\left(2.0-3.0 \mathrm{~g} \mathrm{dry} \mathrm{wt}^{-1}\right)$ in phosphate buffer. The rate of oxygen 
uptake was monitored, and the values obtained were corrected for endogenous respiration.

Preparation of cell extracts. Fresh cells, prepared in the same way as for oxygen uptake measurement, were suspended in phosphate buffer and disrupted sonically by three 2 min bursts using an ultrasonic disruptor UD-200 (TOMY). Cellular debris was removed by centrifugation at $15000 \mathrm{~g}$ and $0{ }^{\circ} \mathrm{C}$ for $10 \mathrm{~min}$. Acetone was added at $10 \%(\mathrm{v} / \mathrm{v})$ to the clear supernatant and the mixture was used immediately for enzyme assays.

Measurement of C230 activity. C23O activity was measured spectrophotometrically by the increase in $A_{375}$ concomitant with the formation of 2-hydroxymuconic semialdehyde. Reaction mixtures contained $0.1 \mathrm{mM}$ catechol and cell extract in phosphate buffer $(\mathrm{pH} 7.0)$ at $24^{\circ} \mathrm{C}$ and the amount of 2 hydroxymuconic semialdehyde formed was estimated as described by Nakazawa \& Yokota (1973). Specific activity is expressed as $\mu \mathrm{mol}$ product formed $\mathrm{min}^{-1}(\mathrm{mg} \text { protein })^{-1}$. The quantity of protein in the cell extract was determined by the method of Lowry using BSA as the standard.

On agar plates, $E$. coli clones expressing $\mathrm{C} 23 \mathrm{O}$ activity were detected by the catechol spray test using $100 \mathrm{mM}$ catechol in phosphate buffer ( $\mathrm{pH} 7 \cdot 0)$.

Extraction and identification of metabolites from bacterial cultures. E. coli cells harbouring recombinant plasmids were incubated with $300 \mathrm{mg} \mathrm{l}^{-1}$ aniline or o-toluidine in $100 \mathrm{ml}$ mineral salts medium at $30^{\circ} \mathrm{C}$ overnight with rotary shaking. Cells were removed by centrifugation at $12000 \mathrm{~g}$ and $4^{\circ} \mathrm{C}$ for $10 \mathrm{~min}$. The supernatant was adjusted to $\mathrm{pH} 2$ with phosphoric acid and extracted with equal volumes of ethyl acetate. Extracts were dried over sodium sulfate and ethyl acetate was removed by evaporation under vacuum using a rotary evaporator. Residues were taken up in small volumes of acetone. After separation by preparative TLC using $20 \%$ $(\mathrm{w} / \mathrm{v})$ potassium chloride as the solvent system, metabolites were scraped from the silica gel plate, extracted with ethyl acetate, and stored at $-20^{\circ} \mathrm{C}$ prior to analysis.

The metabolites were identified by GC-MS analysis using a Hewlett Packard model 5890 II gas chromatograph fitted with a $5 \%$ diphenyl and $95 \%$ dimethylpolysiloxane capillary column HP5 (30 m $\times 0.32 \mathrm{~mm})$ and JMS Automass model 150 mass spectrograph (JEOL) at an ionization potential of $70 \mathrm{eV}$. Helium was used as the carrier gas. The oven temperature was raised continuously from 50 to $200{ }^{\circ} \mathrm{C}$ at a rate of $20^{\circ} \mathrm{C} \mathrm{min}$.

\section{RESULTS AND DISCUSSION}

\section{Isolation and identification of aniline-assimilating bacteria}

During $7 \mathrm{~d}$ enrichment batch cultivation, the colour of the culture gradually turned yellow, which probably indicated the formation of an intermediate, 2hydroxymuconic semialdehyde, from aniline. Several aniline-assimilating bacteria were isolated from the culture by repeated subculture on MSA agar plates. An aniline-degradation test was performed, using six fastgrowing bacteria (named YAA, YAB, YAD, YAI, YAJ and YAK, respectively), on MSA agar plates. Aniline concentration in the culture was determined using the diazo-coupling method (Snell et al., 1954). As shown in Fig. 1, when the cells pre-grown on LB medium containing aniline were suspended at $\mathrm{OD}_{600}=1.0 \mathrm{in} \mathrm{MSA}$

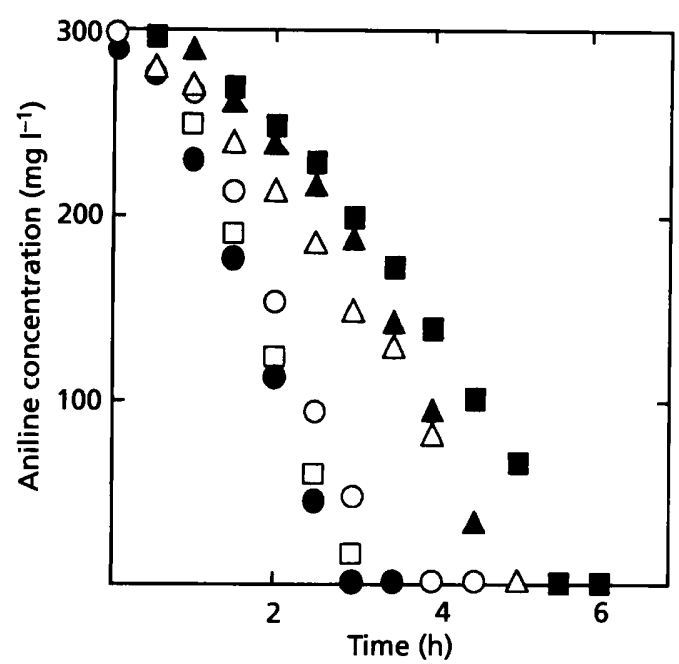

Fig. 1. Aniline-degradation test by isolated strains. MSA was inoculated with an exponentially growing culture of each isolate, and incubated with rotary shaking at $30^{\circ} \mathrm{C}$. The initial cell concentration was 1.0 at $O D_{600}$. Aniline concentration was determined as described in Methods. Strains: $O, Y A A ; \triangle, Y A B$; $\square$, YAD; O, YAl; $\triangle$, YAJ; $\square$, YAK.

medium, these strains degraded $300 \mathrm{mg}$ aniline $\mathrm{l}^{-1}$ within $6 \mathrm{~h}$ without a lag period. All the cultures turned yellow with the progress of aniline degradation as was observed in the enrichment culture. Therefore, it was presumed that aniline was metabolized via catechol through the pathway involving meta-cleavage of the benzene-ring.

One of the isolates, designated strain YAA, was Gramnegative, short rod shaped, oxidase-negative, catalasepositive, non-motile and showed no growth in anaerobic conditions. Acetoin, indole and $\mathrm{H}_{2} \mathrm{~S}$ were not produced. These morphological and biochemical properties are the characteristic criteria for the Acinetobacter genus in Bergey's Manual of Systematic Bacteriology. The API 20 $\mathrm{NE}$ identification system, which is based on 21 phenetic characters, also classified strain YAA as Acinetobacter junii with a $91.7 \%$ probability. The partial $16 \mathrm{~S}$ ribosomal RNA sequences of this strain (nt 28-449 and nt 669-983 in the E. coli numbering system, Brosius et al., 1978), the former of which contains variable regions useful for the identification of eubacteria (Rochelle $e t$ al., 1995) and proteobacteria (Woese, 1987), were compared to other sequences in DNA databases such as GenBank, EMBL and DDBJ. The sequences determined showed strong homology to those of Acinetobacter strains.

Strain YAA is able to utilize aniline and o-toluidine as the sole source of carbon, but not $m$-toluidine, $p$ toluidine, chloroanilines, aminophenols or diaminobenzenes. Additionally, strain YAA is able to grow on phenol, benzoate, salicylate and naphthalene as the sole source of carbon. However, we could detect no C23O activity except during aniline or $o$-toluidine metabolism (data not shown). 


\section{Loss of aniline-assimilation activity}

A culture of strain YAA treated with acridine orange was spread onto LB plates. After incubation at $30^{\circ} \mathrm{C}$ for $24 \mathrm{~h}, 400$ of the colonies appearing on the plates were picked out randomly and tested for growth on MSA medium. Thirty-six percent of the colonies could not grow on aniline. This high frequency of loss of aniline assimilation ability induced by acridine orange mutagenesis was observed, but no mutant strain was obtained which lost the ability to grow on benzoate or phenol. One of the mutant strains, designated YAA-113, seemed identical to the wild-type in all respects except for the loss of aniline assimilation ability.

To examine aniline oxidation activity in strains YAA and YAA-113, oxygen uptake measurement of the resting cells of both strains was carried out. The anilineand $o$-toluidine-grown YAA cells showed apparent aniline oxidation activity [aniline-grown cells, $36.6 \mathrm{mg}$ $\mathrm{O}_{2}(\mathrm{~g} \text { dry wt })^{-1} \mathrm{~h}^{-1} ; o$-toluidine-grown cells, $70.9 \mathrm{mg} \mathrm{O}$ $(\mathrm{g} \text { dry wt})^{-1} \mathrm{~h}^{-1}$ ], whereas the aniline- and $o$-toluidinegrown YAA-113 cells showed no activity (below endogenous level). The endogenous respiration subtracted was about $20 \mathrm{mg} \mathrm{O}$ (g dry wt $)^{-1} \mathrm{~h}^{-1}$. In addition, the aniline-grown YAA cells showed strong $\mathrm{C} 23 \mathrm{O}$ activity $\left.[14 \cdot 1 \mathrm{U} \text { (mg protein })^{-1}\right]$, while the anilinegrown YAA-113 cells showed no $\mathrm{C} 23 \mathrm{O}$ activity $\left.\left[<10^{-3} \mathrm{U} \text { (mg protein }\right)^{-1}\right]$. These results demonstrated that the acridine orange treatment caused the concominant loss of aniline oxidation activity and $\mathrm{C} 23 \mathrm{O}$ activity. As the succinate-grown YAA cells showed little aniline oxidation activity $[<6.0 \mathrm{mg} \mathrm{O}$ (g dry $w t)^{-1} h^{-1}$, aniline oxygenase appears to be induced in strain YAA.

\section{Comparison of plasmids in strains YAA and YAA-113}

Fig. 2 shows the results of agarose gel electrophoresis analysis of the plasmid DNA from strains YAA and YAA-113. As shown in Fig. 2(a), there is a difference in the plasmid profiles between both strains, although both strains have several similar plasmids. Strain YAA-113 seems to have lost some plasmid bands of a high molecular size $(>20 \mathrm{~kb})$, which are present in the YAA plasmid DNA. EcoRI digestion of both plasmid DNAs clarified the situation of the lost plasmid DNA (Fig. $2 b$; lanes 1 and 2). The results described above suggested that the aniline-degradation pathway in strain YAA was plasmid-encoded. We designated the putative plasmid encoding the aniline-degrading pathway as pYA1. If strain YAA-113 had lost only one plasmid, it could be deduced to be more than $50 \mathrm{~kb}$ in size, as estimated from the sum of the lost fragment sizes in this curing experiment.

To further characterize the plasmids in strain YAA, we recovered each plasmid band from agarose gel, and analysed the recovered plasmid DNA by EcoRI-digestion. The results confirmed that there were four different plasmids, sizes $3 \cdot 9,10 \cdot 9,14.8$ and $16.0 \mathrm{~kb}$, with some faint bands being the different conformational (a)

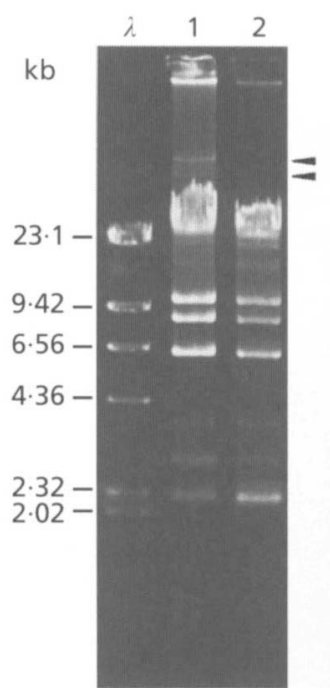

(b)

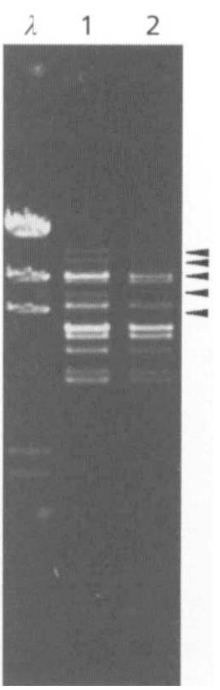

Fig. 2. Agarose gel electrophoresis of plasmid DNA (a) and EcoRI-digested plasmid DNA (b) from strains YAA and YAA-113. Lanes: $\lambda$, Hindlll-digested $\lambda$ DNA; 1 , YAA plasmid DNA; 2 , YAA113 plasmid DNA. Arrowheads indicate differences in the plasmid profile.

forms (probably open circular form) of these plasmids (data not shown). Unfortunately, we were unable to obtain large plasmids ( $>20 \mathrm{~kb}$ ), including pYA1, because of the small amounts of DNA and the difficulty in their recovery. Moreover, the four plasmids described above interfered with the recovery, restriction analysis, and purification by ultracentrifugation of pYA1, owing to their abundant DNA content. Therefore, we decided to clone the aniline-oxidative genes from the total plasmid DNA of strain YAA.

\section{Cloning of the genes specifying aniline oxidation}

Plasmid DNA extracted from strain YAA was digested with SalI, and ligated onto Sall-digested pUC19. The resultant library was transformed into E. coli JM109. One of the transformants developed a yellowish colour on the selection plate containing aniline, but not on the plate without aniline. The colouration was considered to be due to the formation of 2-hydroxymuconic semialdehyde, as is known to occur in clones containing other aromatic compound degradative genes (Takeo et al., 1995). Plasmid DNA was extracted from the clone, and digested by Sall. The recombinant plasmid, designated pAS185, had an $18.5 \mathrm{~kb}$ Sall insert fragment.

\section{Restriction endonuclease analysis of pAS185}

The recombinant plasmid pAS185 was digested with various restriction endonucleases, and a restriction map of the SalI insert fragment was constructed (Fig. 3). The $18 \cdot 5 \mathrm{~kb}$ insert consisted of three different SalI fragments $(3.0,9.0$ and $6.5 \mathrm{~kb})$. Subsequently, the $9.0 \mathrm{~kb}$ Sall 
0
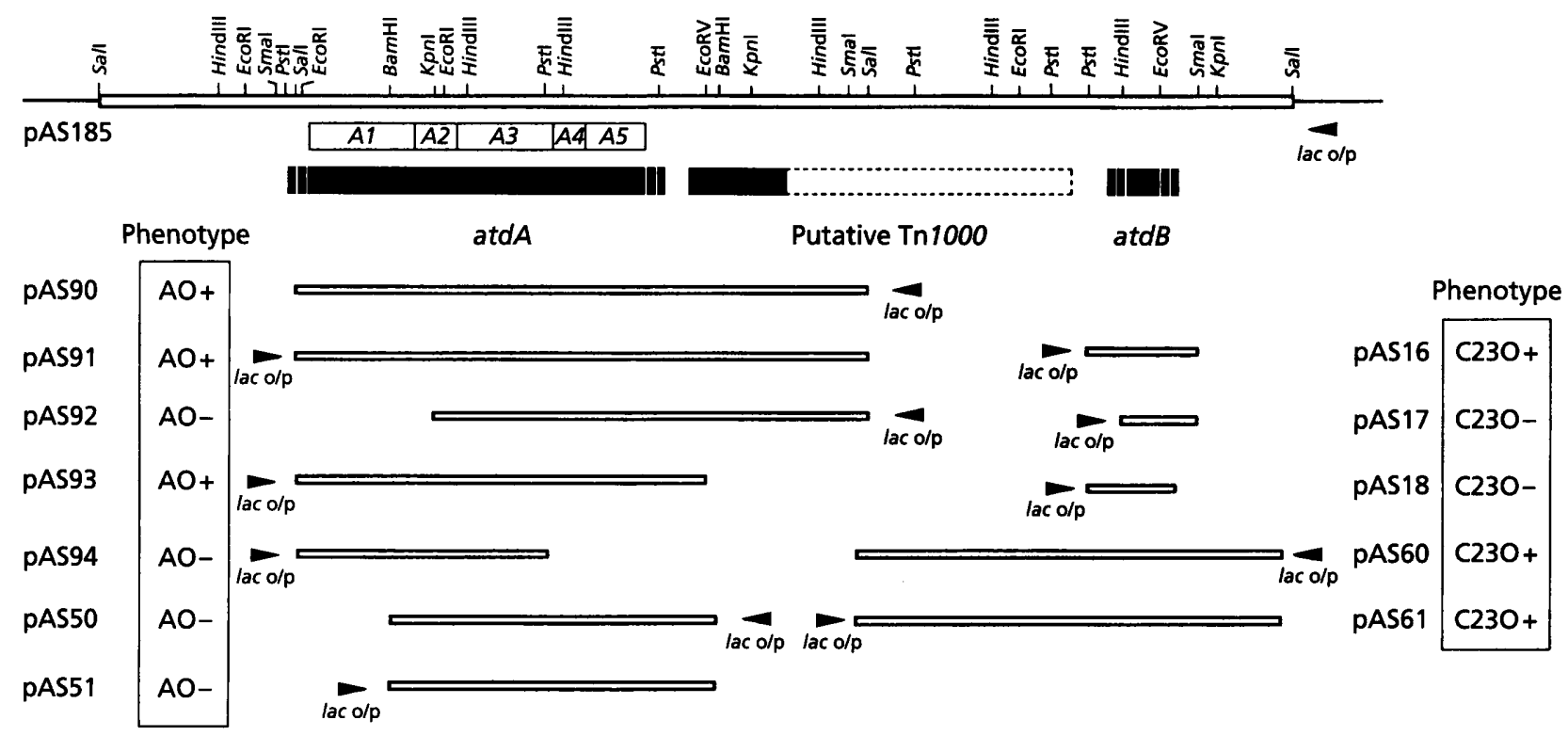

Fig. 3. Restriction map of plasmid pAS185 and subcloned plasmids. The approximate location of the atdA and atdB genes are shown as boxes. Expression of these genes in E. coli JM109 harbouring these plasmids are shown on the right-handside of plasmid designations. The location of ORFs (A1-A5) in the atdA gene and putative Tn 1000 were deduced as described in the text. AO, aniline oxygenase activity; $C 230$, catechol 2,3-dioxygenase activity; +, activity; -, no activity.

fragment was subcloned in both orientations of pUC19 to give pAS90 and pAS91. When these plasmids were in E. coli JM109, both hosts showed a brownish colour on LB plates containing aniline, which probably indicates the accumulation and auto-oxidation of catechol formed from aniline. Because the expression in $E$. coli is not dependent on the direction of the fragment to the vector sequence, the aniline oxygenase gene (atdA) with a functional self-promoter could be presumed to be present in the $9.0 \mathrm{~kb}$ region. By further subcloning, the smallest region expressing the aniline oxidation activity was confirmed to be a $6.3 \mathrm{~kb}$ segment between the SalI and EcoRV sites in the $9.0 \mathrm{~kb}$ fragment. On the other hand, subcloning of the $6.5 \mathrm{~kb}$ Sall fragment into pUC19 resulted in the construction of pAS60, which gave the host $E$. coli $\mathrm{C} 23 \mathrm{O}$ activity. Using catechol spray tests for various subclones, the gene encoding the $\mathrm{C} 23 \mathrm{O}$ activity $(a t d B)$ was found to be located within the $1.5 \mathrm{~kb}$ Pst I$S m a \mathrm{I}$ region in the $6.5 \mathrm{~kb}$ fragment.

We have sequenced the $9 \cdot 0 \mathrm{~kb}$ SalI fragment, and found five ORFs in the sequence, which were presumed to encode a glutamine synthetase-like protein, a GMP synthase-like protein, large and small subunits of dioxygenase, and a reductase component, in this order. We also found the transposase gene sequence of $\operatorname{Tn} 1000$ (Guyer, 1978) over $0.7 \mathrm{~kb}$ downstream of the last ORF. The restriction map of the region between the atdA and atd $B$ genes coincides completely with that of $\operatorname{Tn} 1000$. Therefore, a functional Tn1000 may lie in the region between both genes. The interaction between $\operatorname{Tn} 1000$ and aromatic compound catabolic genes has never been reported, and the detail of these gene sequences is now under investigation.

A plasmid-encoded aniline-degradation pathway was first reported by Anson \& Mackinnon (1984). pCIT1 was discovered in Pseudomonas sp. strain CIT1. After that, Meyers (1992) cloned the aniline oxidative genes from the total DNA of strain CIT1 and showed that the genes encoded 72 and $36 \mathrm{kDa}$ proteins. However, the detail of the genetic organization is still unclear. Another plasmid involved in aniline degradation, pTDN1, was found in P. putida UCC2 which is able to grow on aniline, $m$-toluidine and $p$-toluidine (McClure \& Venables, 1986). To date, the only genetic characterization of aniline oxidation to catechol has been done using pTDN1 (McClure \& Venables, 1987; Saint et al., 1990; Fukumori \& Saint, 1995). The toluidine oxygenase gene, whose product oxidizes aniline, $\mathrm{m}$ toluidine and $p$-toluidine to the corresponding catechols, was located within a $9 \cdot 3 \mathrm{~kb}$ HindIII fragment of pTDN1. Fukumori \& Saint have found several ORFs in this fragment, three of which were presumed to encode large and small subunits of terminal dioxygenase and an electron-transfer protein, usually found in the multicomponent oxygenase enzyme system. In addition, they found a glutamine synthetase gene-like sequence and an IS1071 sequence with $1 \mathrm{bp}$ substitution. We also found glutamine synthetase gene-, GMP synthase gene- and Tn1000-like sequences. Since glutamine synthetase and GMP synthase mediate the addition of amido groups to glutamate and the release of amido groups from glutamine, respectively, both enzyme-like proteins could 
(a)

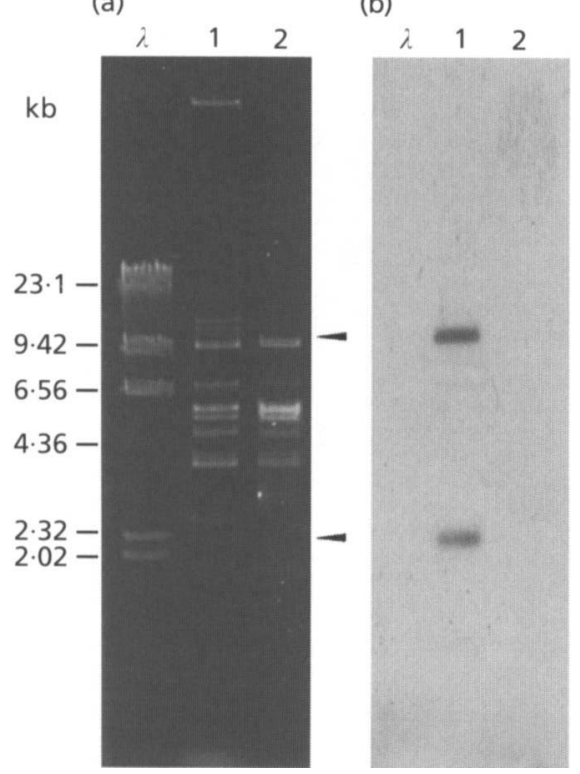

Fig. 4. Southern hybridization of YAA and YAA-113 plasmids with a BamHI fragment encoding the atdA gene of pAS90. (a) Agarose gel electrophoresis of YAA and YAA-113. Lanes: $\lambda$, Hindlll-digested $\lambda$ DNA; 1 , EcoRI-digested YAA plasmid DNA; 2 , EcoRI-digested YAA-113 plasmid DNA. (b) Detected signals of corresponding Southern blot of (a) after hybridization with a fluorescein-labelled $5 \mathrm{~kb}$ BamHI fragment of pAS90. Arrowheads indicate positions of the DNA fragments $(9.5$ and $2.2 \mathrm{~kb}$ ) to which the probe hybridized.

be involved in the recognition and release of aniline amido-groups.

At present, we are unable to compare our sequence with the sequence of the HindIII fragment from pTDN1 directly, because the latter has not been published or registered in any nucleotide database yet. However, the restriction maps of both sequences are quite different.

\section{Identification of intermediates from aniline or o- toluidine in recombinant $E$. coli}

After E. coli JM109 harbouring pAS90 was grown on aniline, a metabolite was extracted from the culture. It showed a TLC $R_{\mathrm{f}}$ value of $0 \cdot 83$, identical to that of authentic catechol. The identity of the product was confirmed by GC-MS analysis. Evidence for catechol was the molecular ion at $m / z 110\left(M^{+}, 100 \%\right)$, which agreed with the molecular formula of $\mathrm{C}_{6} \mathrm{H}_{6} \mathrm{O}_{2}$. Major fragment ions were at $m / z 92\left(M^{+}-\mathrm{H}_{2} \mathrm{O}, 11 \%\right), 81$ $\left(\mathrm{M}^{+}-\mathrm{CHO}, 9.6 \%\right)$ and $64\left(\mathrm{M}^{+}-\mathrm{H}_{2} \mathrm{O},-\mathrm{CO}, 43 \%\right)$. When this strain was grown on o-toluidine, a purplebrownish product accumulated. The mass spectrum of the purple-brownish product showed that there was a molecular ion at $m / z 124\left(M^{+}, 100 \%\right)$, which agreed with the molecular formula of 3-methylcatechol, $\mathrm{C}_{7} \mathrm{H}_{8} \mathrm{O}_{2}$, as expected. Major fragment ions were at $\mathrm{m} / z$ $106\left(\mathrm{M}^{+}-\mathrm{H}_{2} \mathrm{O}, 22 \%\right), 95\left(\mathrm{M}^{+}-\mathrm{CHO}, 8.3 \%\right)$ and 78 $\left(\mathrm{M}^{+}-\mathrm{H}_{2} \mathrm{O},-\mathrm{CO}, 64 \%\right)$. The GC-MS analyses of the products accumulated in recombinant $E$. coli prove that the aniline oxygenase gene $(\operatorname{atd} A)$ is encoded on the cloned $9.0 \mathrm{~kb}$ Sall fragment.

These results indicate that anilines are degraded via catechols in strain YAA, and this pathway is consistent with previous studies (Aoki et al., 1983; Lyons et al., 1984). We were unable to detect the presence of $c i s$-diol compounds which are found as precursors of catechol in aromatic compound oxidation (Gibson et al., 1970; Axcell \& Geary, 1975; Shirai, 1986; Eaton \& Timmis, 1986) by GC-MS analyses.

\section{Evidence for the existence of the atdA gene on plasmid pYA1}

To confirm the existence of atdA on plasmid pYA1, Southern hybridization studies were carried out. A $5.0 \mathrm{~kb}$ BamHI fragment was prepared from the SalI insert fragment in pAS90, fluorescein-labelled, and used as a probe for the hybridization studies. As shown in Fig. 4, the probe hybridized to 2.2 and $9.5 \mathrm{~kb}$ EcoRI-digested fragments in the plasmid DNA of strain YAA, but not in that of the cured strain YAA-113 (in the case of strain YAA-113, such fragments could not be observed in the electrophoresis photograph). The sizes were similar to those expected from the restriction map (Fig. 3). This result indicates that the cloned SalI fragment was derived from the plasmid DNA of Acinetobacter sp. strain YAA.

\section{REFERENCES}

Amador, J. A., Alexander, M. \& Zika, R. G. (1991). Degradation of aromatic compounds bound to humic acid by the combined action of sunlight and microorganisms. Environ Toxicol Chem 10, 475-482.

Anson, J. G. \& Mackinnon, G. (1984). Novel Pseudomonas plasmid involved in aniline degradation. Appl Environ Microbiol 48, 868-869.

Aoki, K., Shinke, R. \& Nishira, H. (1983). Metabolism of aniline by Rhodococcus erythropolis AN-13. Agric Biol Chem 47, 1611-1616.

Axcell, B. C. \& Geary, P. J. (1975). Purification and some properties of a soluble benzene-oxidizing system from a strain Pseudomonas. Biochem J 146, 173-183.

Birnboim, H. C. \& Doly, J. (1979). A rapid alkaline extraction procedure for screening recombinant plasmid DNA. Nucleic Acids Res 7, 1513-1523.

Brosius, J., Palmer, M. L., Kennedy, P. J. \& Noller, H. F. (1978). Complete nucleotide sequence of a $16 \mathrm{~S}$ ribosomal RNA gene from Escherichia coli. Proc Natl Acad Sci USA 75, 4801-4805.

Eaton, R. W. \& Timmis, K. N. (1986). Characterization of a plasmid-specified pathway for catabolism of isopropylbenzene in Pseudomonas putida RE204. J Bacteriol 168, 123-131.

Fuchs, K., Schreiner, A. \& Lingens, F. (1991). Degradation of 2methylaniline and chlorinated isomers of 2-methylaniline by Rhodococcus rhodochrous strain CTM. J Gen Microbiol 137, 2033-2039.

Fukumori, F. \& Saint, C.P. (1995). Analysis of the aniline degradation pathway of Pseudomonas putida UCC2 (pTDN1). Fifth International Symposium on Pseudomonas: Biotechnology and Molecular Biology, abstract, p. 70. 
Gibson, D. T., Hensley, M., Yoshioka, H. \& Mabry, T. J. (1970). Formation of (+)-cis-2,3-dihydroxy-1-methylcyclohexa-4,6diene from toluene by Pseudomonas putida. Biochemistry 9, 1626-1630.

Guyer, M. (1978). The gamma delta sequence of $\mathrm{F}$ is an insertion sequence. J Mol Biol 126, 135-140.

Hasegawa, T. (1985). Biseibutsu no bunrui to doutei. Tokyo: Gakkai Shuppan Center.

Juni, E. (1984). In Bergey's Manual of Systematic Bacteriology, vol. 1, pp. 303-307. Edited by N. R. Krieg \& J. G. Holt. Baltimore: Williams \& Wilkins.

Konopka, A., Knight, D. \& Turco, R. F. (1989). Characterization of a Pseudomonas sp. capable of aniline degradation in the presence of secondary carbon sources. Appl Environ Microbiol 55, $385-389$.

Loidl, M., Hinteregger, C., Ditzelmuller, G., Ferschl, A. \& Streichsbier, F. (1990). Degradation of aniline and monochlorinated anilines by soil-borne Pseudomonas acidovorans strain. Arch Microbiol 155, 56-61.

Lyons, C. D., Katz, S. \& Bartha, R. (1984). Mechanisms and pathways of aniline elimination from aquatic environments. Appl Environ Microbiol 48, 491-496.

Lyons, C. D., Katz, S. E. \& Bartha, R. (1985). Persistence and mutagenic potential of herbicide-derived aniline residues in pond water. Bull Environ Contam Toxicol 35, 696-703.

McClure, N. C. \& Venables, W. A. (1986). Adaptation of Pseudomonas putida $\mathrm{mt}-2$ to growth on aromatic amines. J Gen Microbiol 132, 2209-2218.

McClure, N. C. \& Venables, W. A. (1987). pTDN1, a catabolic plasmid involved in aromatic amine catabolism in Pseudomonas putida mt-2. J Gen Microbiol 133, 2073-2077.

Meyers, N. L. (1992). Molecular cloning and partial characterization of the pathway for aniline degradation in Pseudomonas sp. strain CIT1. Curr Microbiol 24, 303-310.
Nakazawa, T. \& Yokota, T. (1973). Benzoate metabolism in Pseudomonas putida (arvilla) mt-2, demonstration of two benzoate pathways. J Microbiol 115, 262-267.

Rochelle, P. A., Will, J. A. K., Fry, J. C., Jenkins, G. J. S., Parkes, R. J., Turley, C. M. \& Weightman, A. J. (1995). Extraction and amplification of $16 \mathrm{~S}$ rRNA genes from deep marine sediments and seawater to assess bacterial community diversity. In Nucleic Acids in the Environment, pp. 219-239. Edited by J. T. Trevors \& J. D. van Elsas. Berlin: Springer.

Saint, C. P., McClure, N. C. \& Venables, W. A. (1990). Physical map of the aromatic amine and $m$-toluate catabolic plasmid pTDN1 in Pseudomonas putida: location of a unique meta-cleavage pathway. J Gen Microbiol 136, 615-625.

Sambrook, J., Fritsch, E. F. \& Maniatis, T. (1989). Molecular Cloning: a Laboratory Manual, 2nd edn. Cold Spring Harbor, NY: Cold Spring Harbor Laboratory.

Shirai, K. (1986). Screening of microorganisms for catechol production from benzene. Agric Biol Chem 50, 2875-2880.

Snell, F. D. (1954). In Colorimetric Methods of Analysis, 3rd edn, vol. IV, pp. 198-199. Amsterdam: Van Nostrand.

Southern, E. M. (1975). Detection of specific sequences among DNA fragments separated by gel electrophoresis. $J \mathrm{Mol}$ Biol 98, 503-517.

Takeo, M., Maeda, Y., Okada, H., Miyama, K., Mori, K., Ike, M. \& Fujita, M. (1995). Molecular cloning and sequencing of the phenol hydroxylase gene from Pseudomonas putida BH. J Ferment Bioeng 79, 485-488.

Woese, C. R. (1987). Bacterial evolution. Microbiol Rev 51, 221-271.

Zeyer, J., Wasserfallen, A. \& Timmis, K. (1985). Microbial mineralization of ring-substituted anilines through an orthocleavage pathway. Appl Environ Microbiol 50, 447-453.

Received 30 April 1996; revised 5 August 1996; accepted 2 October 1996. 